Original Article

\title{
Fatigue strength of steel plate girder railway bridges with butt joints reinforced with one-sided rhomb-shaped cover plates
}

\author{
Bernard Wichtowski ${ }^{1}$, Krzysztof Konecki 2* \\ 1 West Pomeranian University of Technology, Szczecin, Poland; marek.wichtowski@zut.edu.pl (B.W.) \\ 2 Saferoad Pomerania Sp. z o.o., Szczecin, Poland \\ * Correspondence: krzysztof.konecki@saferoad.pl; Tel.: +48-608-630-932 (K.K.)
}

Received: 02.04.2021; Accepted: 27.05.2021

\begin{abstract}
Due to the long period of service degradation, bridge structures require periodic technical inspections and assessment of the current load capacity. Since the 1970s, this assessment has been carried out according to the Fitness for Purpose (PUK) criterion. From 2008, the PUK criterion has been replaced with the recommendations of the European Convention on Steel Structures (ECCS). As part of these recommendations, the authors decided to explain the previously obtained unrealistic values of the fatigue class $\Delta \sigma_{c}$ of the bridge butt joints covered with one-sided rhomb-shaped cover plates. The computational analysis performed with the FEM method gave excellent results which are briefly presented in the article.
\end{abstract}

Keywords: steel bridges; welding; welded joints; fatigue

\section{Introduction}

The diagnostic tests carried out by the author ${ }^{1}$ on the technical condition of the railway bridges in operation show that:

- Many objects do not strictly transfer design loads, but safely transfer the actual loads occurring on a given line $[1 \div 3]$;

- Strain gauge tests showed operational stresses significantly lower than the values of stresses calculated from the standard loads, they constituted from 58 to $64 \%$ of these values [1,4];

- In the case of steel, regardless of the degree of its aging, the yield strength $R_{e H}$ was each time not lower than $220 \mathrm{MPa}$ [5];

- In 34 examined bridges from 1936 $\div 1960,437$ butt joints with internal cracks were detected $(2.8 \%)$, the development of which was not found in multiple tests.

The first constructors of steel bridges realized that "the weld is the weakest point of the structure". Due to welding incompatibilities, their load capacity is lower than that of the welded material. The simplest and most economical way to eliminate these differences seemed to be an enlargement of the cross-section of the weld by adding cover plates which would compensate for the weakening of the cross-section. This was done in six welded railway bridges in Poland, built in the years 1937 $\div 1939$, i.e. until the outbreak of World War II (Tab. I).

Table I estimates the effect of rhomb-shaped cover plates on the values of the characteristic stresses in the butt joints of the bridges. Column 4 presents the values of stresses due to permanent load, and column 5 - the values of permanent loads and standard loads of rolling stock, taking into account dynamic effects. The standard stress was determined for the basic load system, assuming the load class of $k=+2$. Column 6 presents the values of stresses caused by the constant and moving load on the ET21 locomotive, and columns 7 and 8 - data from NDT tests of butt joints in these bridges. In contrast, the table also includes a railway bridge built by the Germans in 1936. The contractor, knowing that there are 36 cracks in the two repaired web joints of $\mathrm{h}=3.0 \mathrm{~m}$, left the object without reinforcement. Fourfold studies did not show their development. Also, the calculations did not show an emergency risk. The data in the table shows that the rhomb-shaped cover plates reduce the stresses in column 5 with a value from 12.9 to $27.5 \mathrm{MPa}$, and the stresses in column 6 by $7.5 \div 16.1 \mathrm{MPa}$. This means a stress reduction from 9.4 to $25.5 \%$.

According to the authors, the time of safe operation of such bridges is best estimated on the basis of the opinion resulting from the observation of the behaviour of similar structures. At the same time, each detected welding imperfection should be subjected to a synthetic analysis, which will allow to determine whether the imperfection is acceptable from the point of view of fracture mechanics and the actual joint's load condition. 
The Fitness for Purpose (PUK) criteria should then be applied. This approach was introduced in several world standards since the 1970s [6,7] - Figure 1. The authors used the methodology defined by the PUK criteria in the analysis of the durability of bridges presented in four publications.

Table I. Schemes of girders and stresses in butt joints with one-sided rhomb-shaped cover plates (numerator values) and without the rhomb-shaped cover plates (denominator values) and NDT test data

\begin{tabular}{|c|c|c|c|c|c|c|c|}
\hline \multirow{3}{*}{$\begin{array}{l}\text { Line and } \\
\text { the year of } \\
\text { construction }\end{array}$} & \multirow{3}{*}{$\begin{array}{c}\text { Bridge } \\
\text { No. }\end{array}$} & \multirow{3}{*}{$\begin{array}{c}\text { Scheme of the girder and } \\
\text { location of the joint with } \\
\text { cracks }\end{array}$} & \multirow{2}{*}{\multicolumn{3}{|c|}{$\begin{array}{l}\text { Stresses in MPa } \\
\text { system of loads }\end{array}$}} & \multicolumn{2}{|c|}{ Number of } \\
\hline & & & & & & \multirow[t]{2}{*}{ x-rays } & \multirow[t]{2}{*}{ Cracks } \\
\hline & & & $\begin{array}{c}\text { permanent } \\
\text { loads }\end{array}$ & P-norm. & P-eksp. ${ }^{1)}$ & & \\
\hline 1 & 2 & 3 & 4 & 5 & 6 & 7 & 8 \\
\hline $\begin{array}{l}\text { Nasielsk- } \\
\text {-Toruń } \\
1937,1938, \\
1938,1939\end{array}$ & $\begin{array}{c}\text { I } \\
\text { II } \\
\text { III } \\
\text { IV }\end{array}$ & $\underset{20200}{a b c}$ & $\begin{array}{l}\mathrm{Sa}_{\mathrm{a}}=14.3 / 16.8 \\
\mathrm{Sb}=15.1 / 17.1 \\
\mathrm{Sc}_{\mathrm{c}}=15.4 / 17.0\end{array}$ & $\begin{array}{r}116.1 / 136.5 \\
122.1 / 138.1 \\
123.7 / 136.6 \\
\end{array}$ & $\begin{array}{l}68.4 / 80.4 \\
74.4 / 84.2 \\
72.4 / 79.9 \\
\end{array}$ & $\begin{array}{c}88 \\
48 \\
96 \\
144\end{array}$ & $\begin{array}{c}8 \\
6 \\
48 \\
39\end{array}$ \\
\hline $\begin{array}{l}\text { Łódź- } \\
\text { Dębica } \\
1938\end{array}$ & V & 22400 & $\begin{array}{l}\mathrm{Sa}_{\mathrm{a}}=10.3 / 13.8 \\
\mathrm{Sb}=12.0 / 14.3 \\
\mathrm{Sc}_{\mathrm{c}}=12.8 / 14.7\end{array}$ & $\begin{array}{l}80.8 / 108.3 \\
93.6 / 111.1 \\
99.0 / 113.9 \\
\end{array}$ & $\begin{array}{l}47.0 / 63.1 \\
53.9 / 63.9 \\
56.8 / 65.3 \\
\end{array}$ & 128 & 5 \\
\hline $\begin{array}{c}\text { Warszawa- } \\
\text {-Eowicz } \\
1937\end{array}$ & VI & 9000 & $\mathrm{Sa}=5.7 / 7.3$ & $96.0 / 123.2$ & $51.1 / 65.5$ & 32 & - \\
\hline $\begin{array}{l}\text { Poznań- } \\
\text {-Szczecin } \\
1936\end{array}$ & VII & $\frac{32400}{3}$ & $\mathrm{Sa}=24.0$ & 89.9 & $62.3^{2)}$ & 80 & 36 \\
\hline $\begin{array}{l}\text { 1) ET21 locon } \\
\text { 2) } 2 \times \quad \text { Pt31 } \\
\text { permanent lo }\end{array}$ & $\begin{array}{l}\text { ve }+ \text { per } \\
\text { am loco }\end{array}$ & $\begin{array}{l}\text { ent load } \\
\text { ves with 32D29 tenders + }\end{array}$ & & & In total & 616 & 142 \\
\hline
\end{tabular}

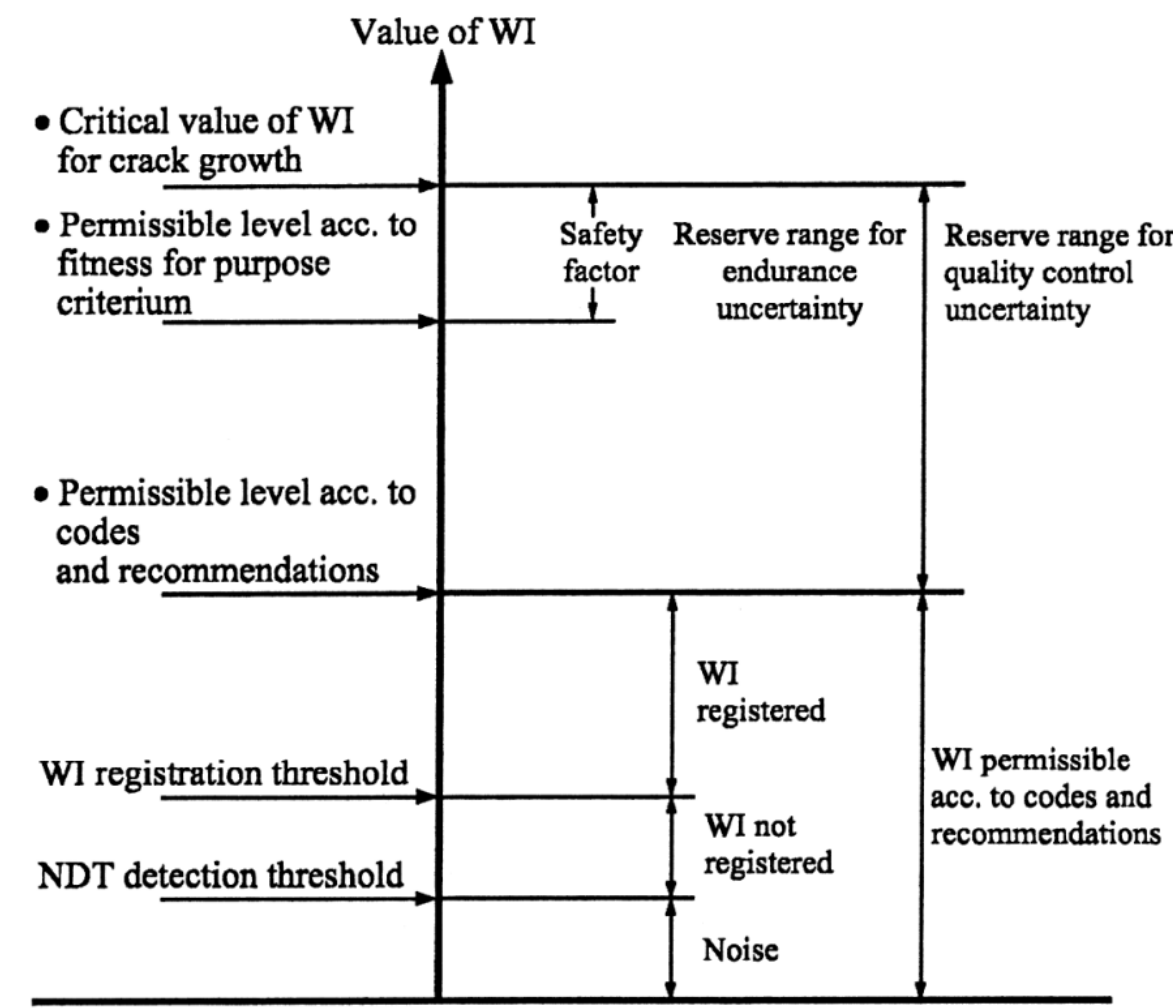

Fig. 1. Levels of acceptability of welding imperfections according to PUK [6] 
Taking into account the above facts, in the years 2003-2011, new standards with guidelines for the assessment of the load capacity of existing bridges were accepted by Canada, Great Britain, Denmark, Switzerland and the USA. The method of calibrated safety factors is included. Reduced requirements for newly designed structures as well as for their further operation were adopted. The assessment of the load capacity of old and long-operated bridges has been discussed in detail, among others, in $[2,8,9]$ and in the total of 142 references provided there $(62+35+45)$.

\section{Own research}

In the case of welding, the fatigue strength is influenced by various factors, which can only be fully taken into account in experimental studies. New recommendations on fatigue strength for welding imperfections of quality level B and C have been provided in PN-EN ISO 5817:2014 and in the guidelines of the European JRC and ECCS [10,11] regarding the fatigue life of bridges. In situ qualitative tests of butt welds in 155 exploited bridges and laboratory tests of their butt joints were carried out [1,12]. They included four groups of bridge joints (Fig. 2).
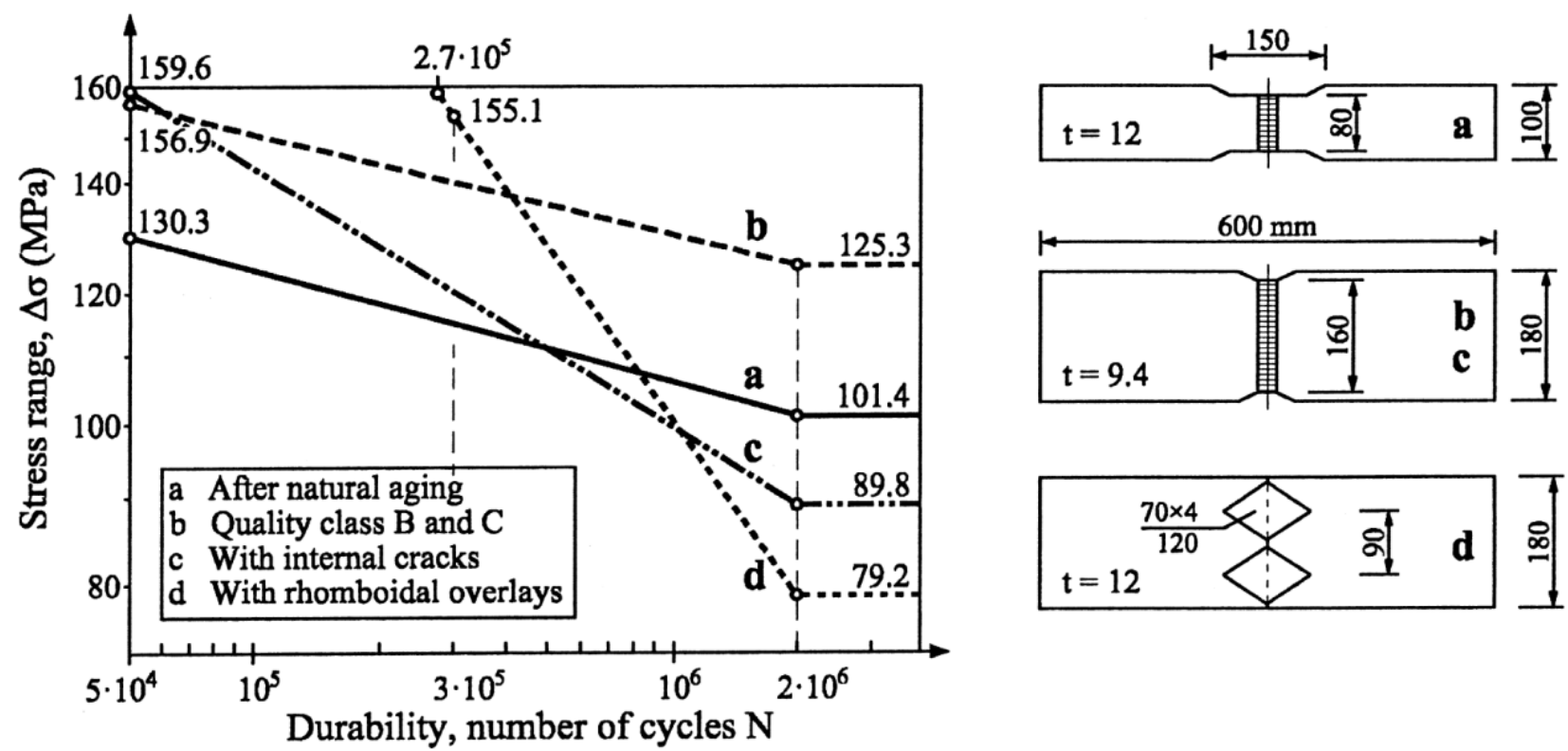

Fig. 2. Comparison of regression lines of 4 types of tested joints with butt welds [1]

The presented fatigue regression lines concern the following tests:

- samples "a" - with butt welds which are spontaneously aged over the period of 45 years, for which the value of infinite fatigue strength is $\mathrm{Z}_{\mathrm{r}}=101.4 \mathrm{MPa}$,

- samples "b" - with butt welds of quality level B and C, for which the value of infinite fatigue strength is $Z_{\mathrm{r} j}=125.3 \mathrm{MPa}$,

- samples "c" - with butt welds with internal (technological) cracks with the value of infinite fatigue strength equal to $Z_{\mathrm{r} j}=89.8 \mathrm{MPa}$,

- samples "d" - with butt joints covered with one-sided rhomb-shaped cover plates with the value of infinite fatigue strength equal to $Z_{\mathrm{r}}=79.2 \mathrm{MPa}$ - Figure 3.

There is a significant decrease in the $Z_{\mathrm{rj}}$ value for the welds with internal cracks and for the welds with rhombshaped cover plates, compared to the $Z_{\mathrm{rj}}$ value of the welds " $b$ ". This decrease is $28.3 \%$ and $36.8 \%$. It is worth noting that at the three stress levels $\sigma_{\max }=80,100 \mathrm{i} 140 \mathrm{MPa}$, seven surface cracks appeared in five samples "d" with the parameters given in Figure 4. 


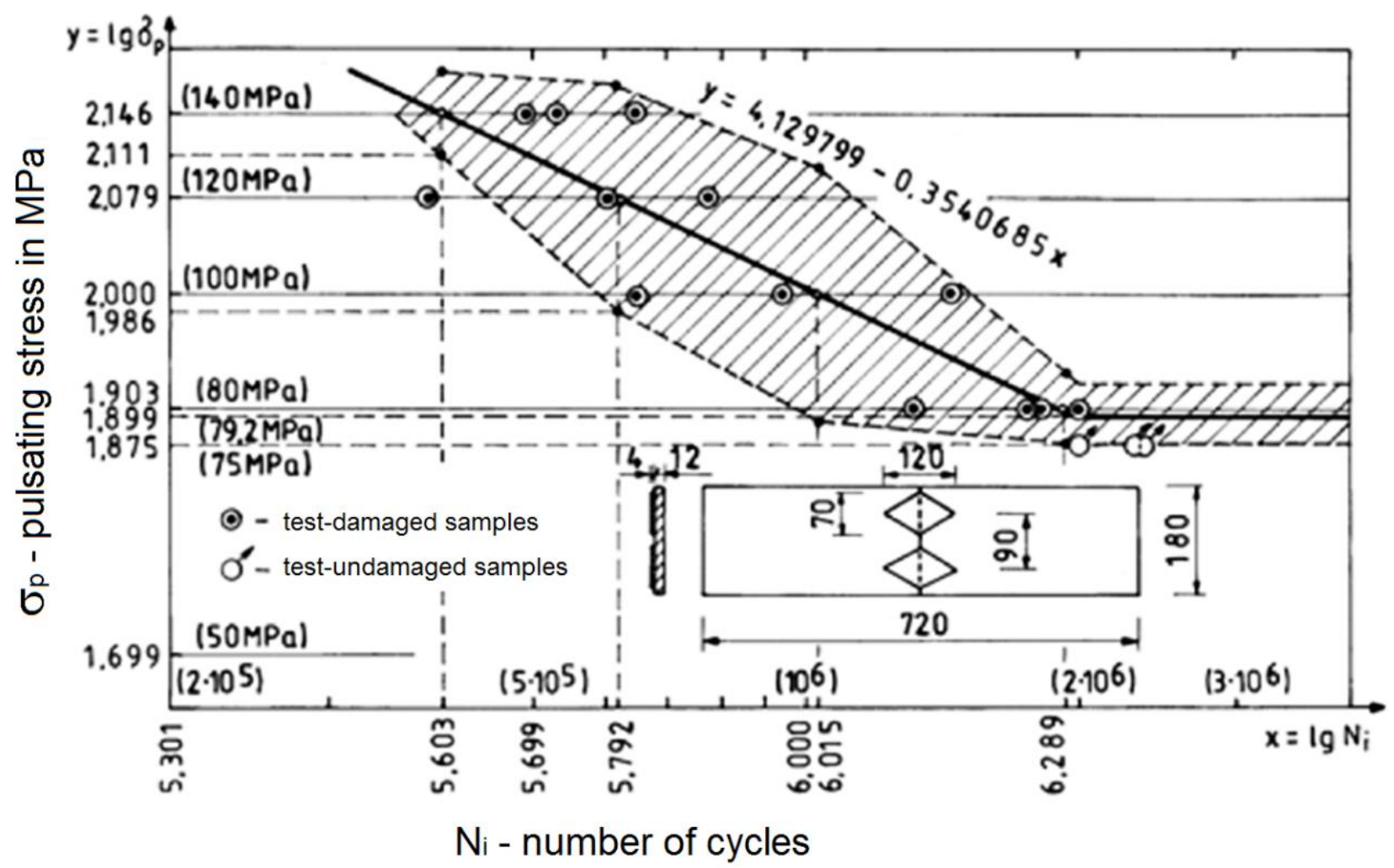

Fig. 3. Test results for "d" samples and the regression line with the confidence interval [1]
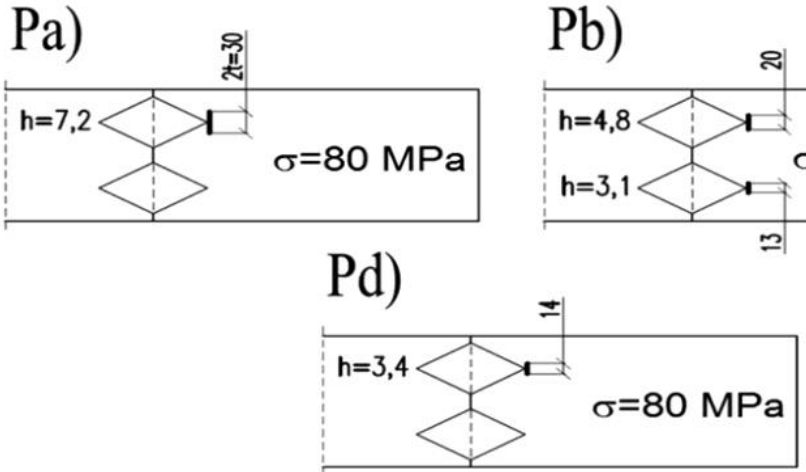

$\mathrm{Pb})$

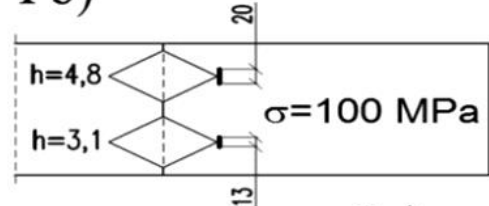

$\mathrm{Pe})$

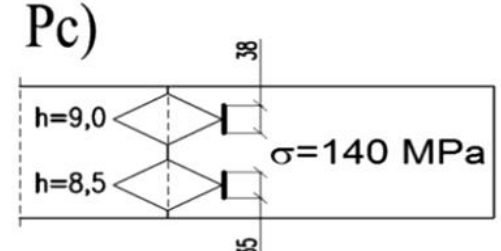

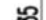

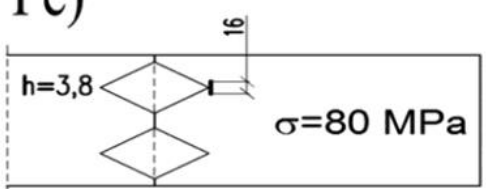

Fig. 4. Test-damaged samples: $\mathrm{Pa}), \mathrm{Pb}), \mathrm{Pc}$ ) and test-undamaged samples: $\mathrm{Pd}), \mathrm{Pe}$ [14]

Inspired by the requirement of the PN-EN-1993-1-9:2007 standard (in accordance with point 7.1 (3), Note 2) on the obligation to compare individual tests with standard requirements, new notch $\Delta \sigma_{c}$ categories have been defined. Using the results of the verification tests from Figure 2, they were determined according to the Czech standard ČSN 731401:1998 and are provided in column 4, table II. At the same time, to illustrate the issue as a whole, the table also shows the values of the FAT fatigue classes at other load cycles. According to PN-EN ISO 5817:2014, for welds, the value of the FAT fatigue class is the range of stress variability $\Delta \sigma_{c}$ in relation to the 2 - million number of Nc cycles determined at the $75 \%$ limit of the average confidence tolerance with a $95 \%$ probability of survival. The obtained FAT values from Table II were commented on in [12]. The authors also support the given conclusion on the non-application of the above recalculation recommendations in operating facilities, i.e. similar to the guidelines of PN-EN 1993-1-10 on the non-use of steel due to brittle cracking in used structures.

The inexplicably low values of the fatigue strength of the joint "d", with one-sided rhomb-shaped cover plates $\left(\Delta \sigma_{\mathrm{c}}=28 \mathrm{MPa}\right)$, obligated the authors to carry out a detailed analysis of the joint. The analysis was presented in three articles published in the journal "Inżynieria i Budownictwo" [13:15]. Due to the obtained "revolutionary" calculation results (casus pascudeus), we would like to present them to a wider group of interested people. 
Table II. Fatigue strength in MPa for 4 welded flange connections

\begin{tabular}{|c|c|c|c|c|c|}
\hline Construction detail & $\begin{array}{l}\text { Type of } \\
\text { the joint }\end{array}$ & $\begin{array}{c}\mathrm{Z}_{\mathrm{rj}} \\
\left(\mathrm{N}=2^{*} 10^{6}\right)\end{array}$ & $\begin{array}{c}\Delta \sigma_{\mathrm{c}} \\
\left(\mathrm{N}=2^{*} 10^{6}\right)\end{array}$ & $\begin{array}{c}\Delta \sigma_{\mathrm{D}} \\
\left(\mathrm{N}=5^{*} 10^{6}\right)\end{array}$ & $\begin{array}{c}\Delta \sigma_{\mathrm{L}} \\
\left(\mathrm{N}=10^{8}\right)\end{array}$ \\
\hline & a & 101 & 38 & 28.0 & 15.4 \\
\hline & $b$ & 125 & 80 & 58.9 & 32.4 \\
\hline & C & 90 & 45 & 33.1 & 18.2 \\
\hline & d & 79 & 28 & 20.6 & 11.3 \\
\hline
\end{tabular}

\section{Analysis of a joint with cover plates}

For the analysis, a joint model with the geometry shown in Figures 2 and 3 was adopted, made of steel with $R_{e H}=249 \mathrm{MPa}$ and $\mathrm{R}_{\mathrm{m}}=360 \mathrm{MPa}$. The stress distribution in the joint was determined by the finite element method (FEM) in the Inventor Nastran program, on the FEM model shown in Figure 5. The stresses were calculated in sections a-d at points 1-1' (Fig. 6) with the assumed tensile forces with the values adopted in the fatigue tests according to figure 3, i.e. $P=162,173,216,260$ and $303 \mathrm{kN}$. They cause stresses in the joint's sheet of 75, 80, 100, 120 and $140 \mathrm{MPa}$. Overall, on the "A" side with rhomb-shaped cover plates (obverse), the stresses were calculated at 208 points, and on the "R" side - reverse at 180 points.

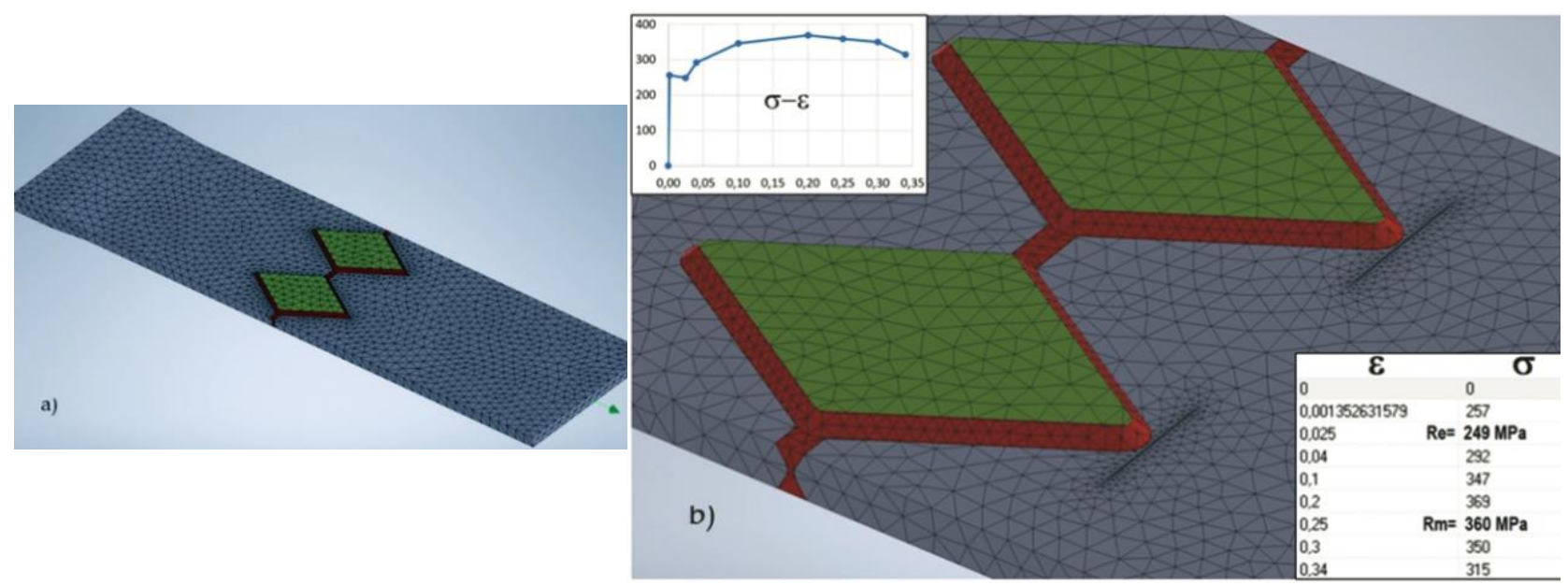

Fig. 5. a) General calculation model b) and cracks and material data of steel [13]

The analysis of values of the tensile stresses of the joints allowed to state that:

- rhomb-shaped cover plates do not reduce the stresses in the butt weld in accordance with the adopted principle of the percentage quotient of their area to the plate area equal to $25.9 \%$ (see Table I);

- the cover plates are a construction ballast, they reduce the value of infinite fatigue strength by about $37 \%$ (see Fig. 2);

- the cover plates take the force increase from the c-c section at their ends, caused by the stress concentration at points $\mathrm{c} 3$ and (c3');

- in the area of the end of the rhomb-shaped cover plates, at points 3 and (3') of cross-section c, there is a stress concentration, the coefficient of which is equal to the quotient of the stress value on the surface "A" for the connection without cover plates $\left(\sigma_{\max }\right)$ and ranges from 1.47 to 1,69 ;

- the above stress concentration, together with the smallest coefficient of concentration from a globular (spherical) non-metallic inclusion of 2.04, are the reasons for the formation of one-sided stochastic cracks already at $\sigma_{\max }=80 \mathrm{MPa}$ (Fig. 4); then $\sigma=80^{*} 1,69^{*} 2,04=275 \mathrm{MPa}$, which is higher than the yield stress of steel $\mathrm{ReH}_{\mathrm{eH}} 249 \mathrm{MPa}[16,17]$. 


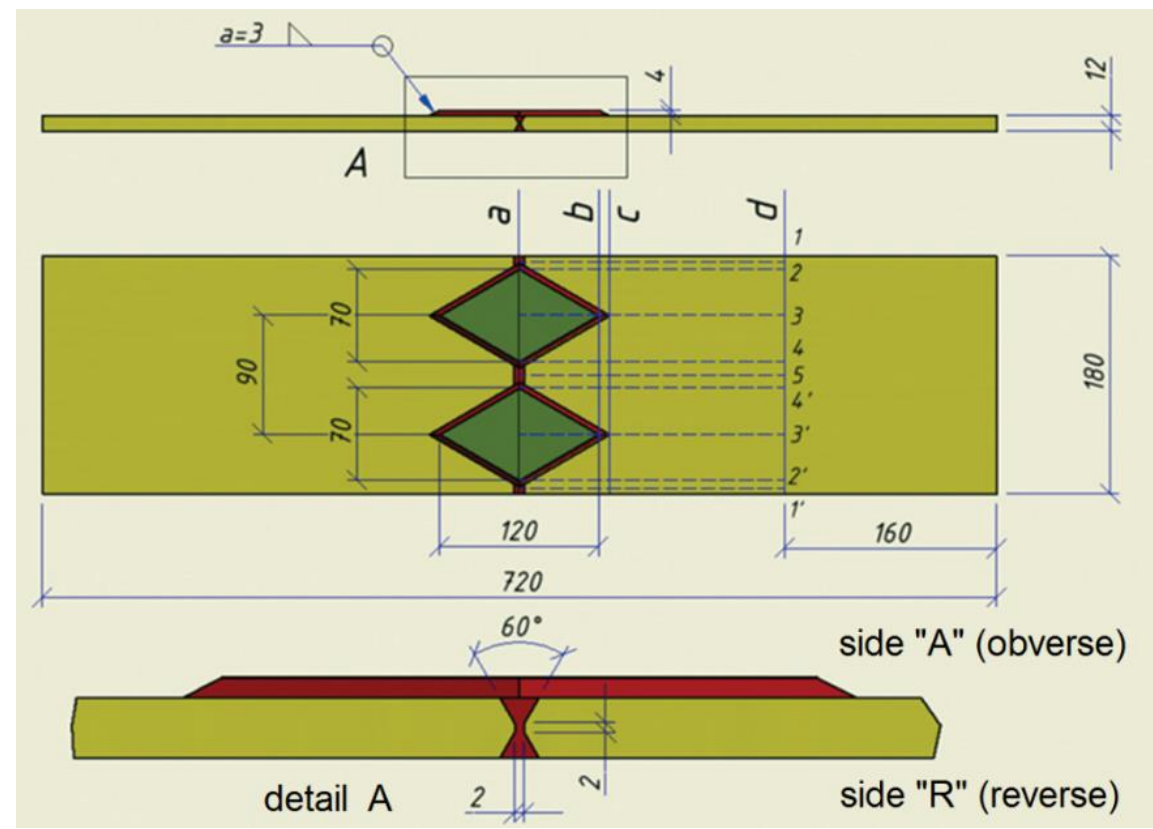

Fig. 6. The view of the tested sample and the location of measurement points [13]

Cracks occurred at three stress levels $\sigma_{\max }=80,100$ and $140 \mathrm{MPa}$ with a varied number of load cycles from 535.000 to 1.990 .200 . These are fatigue cracks, the development of which occurs in stages, as opposed to the rapidly developing cracks in the tests of joints: a, b, c according to Figure 2. All cracks had an analogous fracture shown in Figure 7, with three development trajectories: I - crack initiation, II - growth, III - final fracture. The stress distribution on the circumference of these cracks is always analogous, with the lowest values in the upper zone, the obverse zone. These values are equal to the upper $\mathrm{ReH}_{\mathrm{eH}}$ values of the steel $\mathrm{R}_{\mathrm{eH}}{ }^{\max }=$ $280 \mathrm{MPa}$. On the other hand, the maximum stress of $\sigma \approx 306 \mathrm{MPa}$ occurs at the crack's tip (Fig. 8).

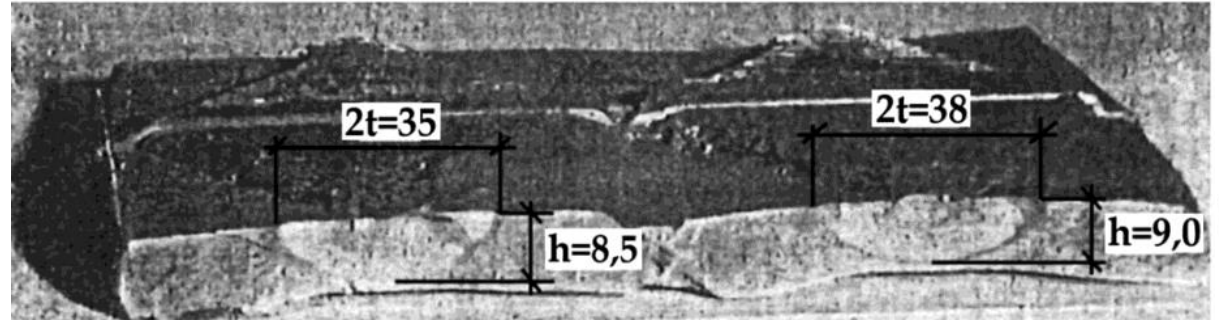

(a)

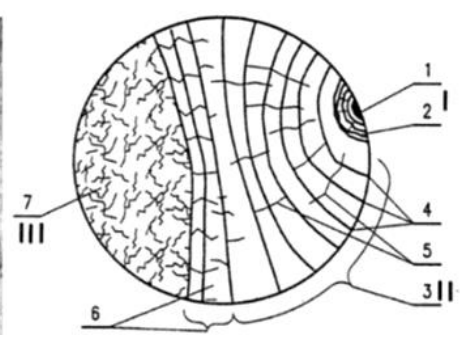

(b)

Fig. 7. a) Macro specimen of cracks of Pc sample b) and the scheme of fatigue crack: 1,2 - fatigue origin, 3 - fatigue zone, 4 - fatigue lines, 5 - ratchet marks, 6 - transition zone, 7 - final fracture $[14,18]$

According to literature analyses, no strict criterion of fracture development in zones II and III, i.e. zones of established fracture development and zones of unstable fracture development during fracture, has not been developed so far. It has not been done since 1913 (C.E. Inglis), despite the development of 64

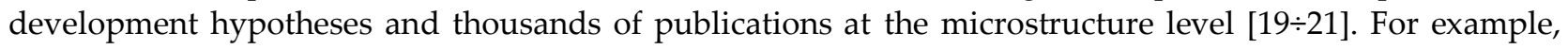
after the chapter entitled "Fatigue crack development" in [19], 469 supplementary references are given. There, the development of cracking is probabilistically described in a way that is generally understandable for specialists.

The authors of the article, using the results of the calculated stresses in the joints of the $\mathrm{Pb}$ and $\mathrm{Pc}$ joints from Figure 8, suggest a new development of part II of the fracture. Two laws of physics were used in the analysis:

- the course of ductile fracture can be stopped at any time by reducing the stress below the yield point of the material;

- the moving peaks of the upper dimension of the fracture with a length of $2 t$, on the obverse surface, will as first reach the elastic stress zones $\mathrm{s}=99 \div 100 \mathrm{MPa}$ and $100 \div 104 \mathrm{MPa}$ and $172 \div 180 \mathrm{MPa}$ and $176 \div 180 \mathrm{MPa}$ (see Fig. 8). This is guaranteed by the geometry of the fracture $-\mathrm{t} / \mathrm{h} \approx 2$ and is confirmed by the scrap analysis (macro specimen analysis), which shows that the fracture grows faster along the obverse than into the material. 

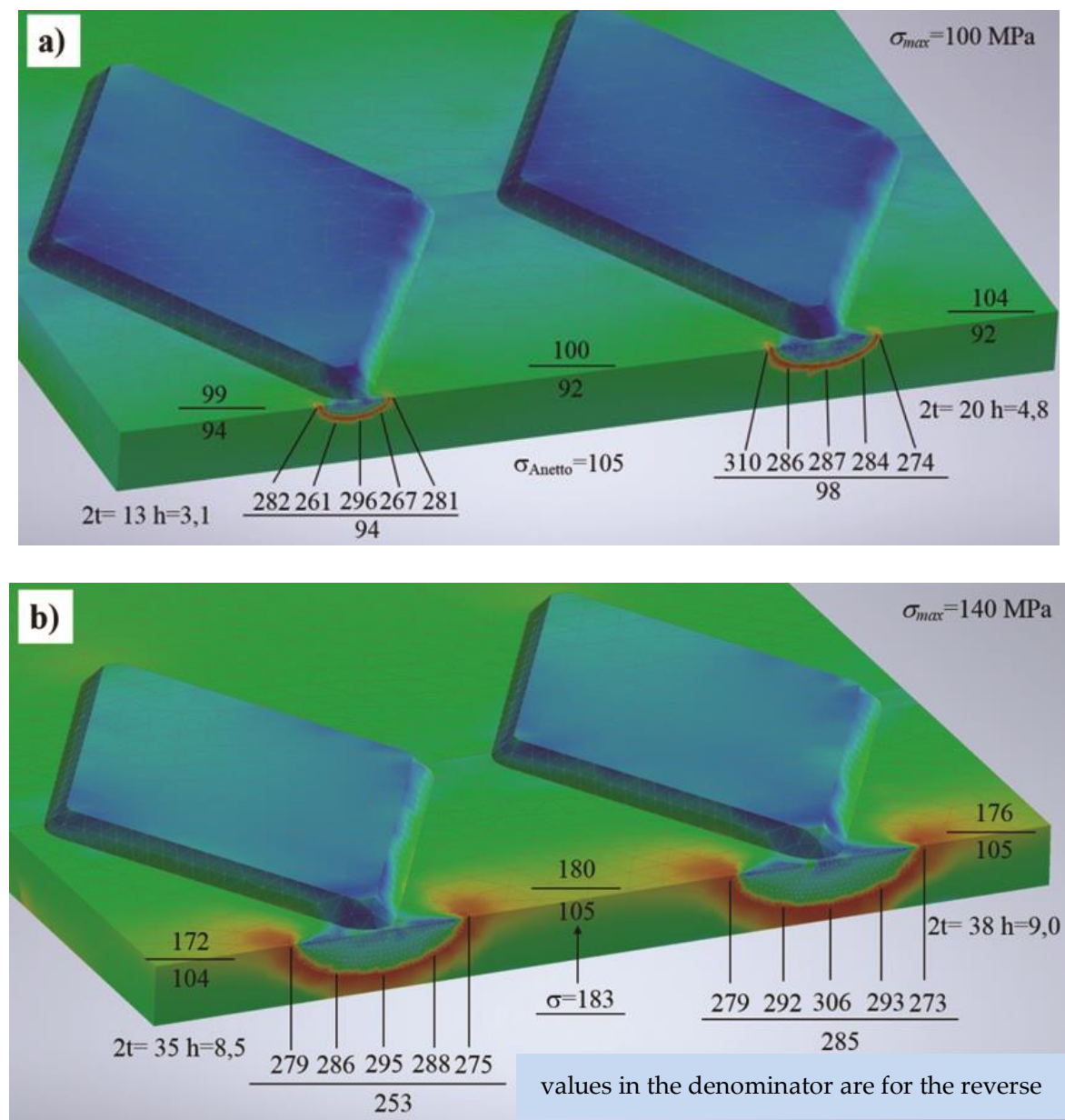

Fig. 8. Stresses in the c-c cross-section for: a) Pb crack, b) Pc cracks [13]

The surface edge stresses on the obverse are reduced to the measured values $273 \div 310 \mathrm{MPa}$, i.e. to the value of the upper yield stress of the material $\left(\mathrm{ReH}_{\mathrm{e}}{ }^{\mathrm{ax}}=280 \mathrm{MPa}\right)$. The development of ductile cracking at the edge points at the level of the obverse disappears. This phenomenon evolves into the neighbouring "deep" points of the fracture and, as part of the principle of stress equalization, successively inhibits the cracking on both sides, proceeding to the top of the fracture. The complete development of cracking in zone II disappears.

In general, it should be stated that in the studies conducted so far there is no single general model for a comprehensive description of fatigue cracks. All models discussed in the literature relate only to the first and second stages of their development. The only model of the transition from the fracture zone to the final fracture known to the authors is the third stage of fracture development developed by A.H. Cottrel and N.J. Petch, discussed in [20]. It is a model of the transition from a plastic to a brittle state. The yield point $\sigma_{\mathrm{pl}}$ was taken as the basis for this transition.

Table III. Analysis of the zone of final fracture cracks in tested samples $\mathrm{Pa}, \mathrm{Pb}, \mathrm{Pc}$

\begin{tabular}{|c|c|c|c|c|c|c|c|c|c|}
\hline $\begin{array}{c}\text { Sample } \\
\text { No. }\end{array}$ & $\begin{array}{l}\sigma_{\max } \\
\mathrm{MPa}\end{array}$ & $\begin{array}{c}\text { Crack } \\
(2 \mathrm{t} / \mathrm{h}) \\
\mathrm{mm}\end{array}$ & $\begin{array}{l}\mathrm{Z}_{\mathrm{rj}}{ }^{1)} \\
\mathrm{MPa}\end{array}$ & $\begin{array}{c}Z_{\text {rjmin }}^{2)} \\
\text { (fig. 3) } \\
\text { MPa }\end{array}$ & $\gamma^{3)}=Z_{\text {rjmin }} / Z_{\text {rj }}$ & $\begin{array}{c}\sigma_{3\left(3^{\prime}\right)} \\
\text { (fig. 8) } \\
\text { MPa }\end{array}$ & $\begin{array}{c}\gamma \sigma_{3\left(3^{\prime}\right)^{4)}} \\
\mathrm{MPa}\end{array}$ & $\begin{array}{c}\sigma_{\mathrm{pl}} \\
\text { (fig. 5) } \\
\mathrm{MPa}\end{array}$ & $\gamma \sigma_{3}=\sigma_{\mathrm{pl}}$ \\
\hline 1 & 2 & 3 & 4 & 5 & 6 & 7 & 8 & 9 & 10 \\
\hline $\mathrm{Pa}$ & 80 & $30 / 7.2$ & 82.9 & 79.2 & 0.955 & 306 & 292 & 280 & $\sigma \approx \sigma_{\mathrm{plmax}}$ \\
\hline $\mathrm{Pb}$ & 100 & $\begin{array}{l}13 / 3.1 \\
20 / 4.8\end{array}$ & 88.7 & 79.2 & 0.893 & $\begin{array}{c}287 \\
(296)\end{array}$ & $\begin{array}{c}256 \\
(264)\end{array}$ & $\begin{array}{l}249 \\
\div 280\end{array}$ & $\begin{array}{l}\sigma=\sigma_{\text {plmax }} \\
\sigma=\sigma_{\text {plmax }}\end{array}$ \\
\hline$P_{c}$ & 140 & $\begin{array}{l}35 / 8.5 \\
38 / 9.0\end{array}$ & 126.3 & 79.2 & 0.627 & $\begin{array}{c}306 \\
(295)\end{array}$ & $\begin{array}{c}192 \\
(185)\end{array}$ & 249 & $\begin{array}{l}\sigma<\sigma_{\mathrm{pl}} \\
\sigma<\sigma_{\mathrm{pl}}\end{array}$ \\
\hline
\end{tabular}

1) Infinite fatigue strength of the joint after fracture, according to the equation "y" - Fig. 3

2) Infinite fatigue strength after $2^{*} 10^{6}$ load cycles,

3) - factor reducing stresses as a result of increasing $\mathrm{N}$ cycles,

4) Reduced stresses before final fracture, proportional to $\gamma$ - that is $\sigma_{3\left(3^{\prime}\right)}$ according to Fig. 8 
When this point is greater than the crack propagation stress, the material is brittle, and vice versa. "Brittle cracking will occur when the applied stress $\sigma$ during crack propagation is equal to the effective energy of the newly formed surface." This means that brittle cracking will occur under the stress of $\sigma=\sigma_{\mathrm{pl}}$ (Fig. 8 and Table III).

An attempt to explain this phenomenon in relation to five cracks in the three damaged joints $\mathrm{Pa}, \mathrm{Pb}, \mathrm{Pc}$ is presented in Table III. In this analysis, the results presented in Figure 3 were used, which were obtained during the fatigue strength tests of the joints in question. This practically applies to the value of $Z_{\mathrm{r}}$ given in the $\mathrm{N}_{\mathrm{i}}$ function.

The determined decrease in the stress value from col. 7, after the crack development has stopped, to the value at the moment of the fracture according to col. 8, was determined from a simple regression determined in Figure 3. The determined stress values at the moment of the fracture of individual joints are from 185 to $292 \mathrm{MPa}$ (col. 8). Practically in accordance with the inequalities given in col. 10, these values according to the hypothesis of A.H. Cottrel and N.J. Petcha decide on the transition to brittle fracture of zone III. The idea of stress equalization $\sigma=\sigma_{\mathrm{pl}}$ is preserved here. The existing minor anomalies in the stress values $\sigma$ for Pa and Pc joints according to col. 8 should be explained by the unknown different values of the stress concentration factors $K_{\sigma}$ of non-metallic inclusions that determined the occurrence of a given crack [see 15].

\section{Summary}

The article is a short summary, an integral part of the computational analyses of the bridge welded butt joint with one-sided cover plates, presented in the triptych published in the journal "Inżynieria $i$ Budownictwo" [13:15]. The analysis of the joint in the process of validation of the adopted model with the finite element method allowed to fully explain the "purposefulness" of its application and to comprehensively define the development of the fatigue crack. The intention of the authors of the article is to familiarize the experts carrying out the assessment of the technical condition of old bridges, with the structure as in the title, with the fact that their computational durability has increased. The cover plates on the butt joints of the bridges are a structural ballast, they reduce the fatigue strength of the joint and have a direct impact on the development of fatigue cracks. The authors' dreams are discussions, consultations and proposals from a group of people interested in the presented issues, which have not been solved for 108 years. For the authors, the results are a big surprise and a revelation, they are a shock. This is especially true of the autor ${ }^{1}$, who learned at the end of his life that he was a compulsive liar. The truth is not a decisive factor, the most important thing is the acceptance of the community dealing with a given field. In this light, the stubborn rejection of new solutions often takes on a different expression [12].

For 50 years of teaching, the author ${ }^{1}$ provided students with the incorrect calculation theory according to Table I. Also, as a co-author of reports to the Ministry of Communications, on many years of research on butt welds in national railway bridges, he incorrectly assessed their durability. How to explain the incorrect assumptions in the published publications when assessing the durability of bridges is performed using the Fitness for Purpose method? These errors were repeated in the accepted conference papers, postponed due to the coronavirus pandemic, i.e. Eurosteel: 2020 in Sheffield, XIIIC-SAHC 2020 in Barcelona and ECF23 in Funchal, Madeira.

It is sad to admit a paradigm shift that defines computational concepts. Also because here the term paradigm is of great economic importance, due to the reduction of the load capacity of certain types of bridges. The presented calculations showed that deterministic methods enable better predicted durability and reliability of elements than probabilistic methods. The cited 64 formulas for fracture velocity are primarily probabilistic descriptions used to estimate physical phenomena such as stopping cracks at the grain boundaries and other microstructural obstacles. A more detailed discussion of these issues in plate girder railway bridges was presented in the paper for the ECF23 European Conference on Fracture 2020, which was to be held in Portugal on June 27 - July 3, 2020.

The results contribute to the ongoing discussion on new forms of assessing the service life of "historical" bridges. It is a global problem. Experts in Poland often assess the durability of old bridges without taking into account the current recommendations and sometimes with inaccurate, sometimes incorrect interpretation of the test results. A question arises: why are they averse to the introduced novelties? As early as 1972, the British, in accordance with BS 153: Past 3A, introduced the division of railway structures into four groups as a function of the number of load cycles. At the same time, the updated standards BS 7910:2013 $\div$ A1:2015 define the guidelines for acceptability of defects in metal structures, and the standard BS 7608:2014 provides provisions for the design and fatigue assessment of steel structures. In the 21st century, five countries introduced new load standards for old bridges. The PN-EN ISO 5817:2014 standard introduces (in 
Annex C) enigmatic additional requirements for fatigue classes of welds (FAT) without explanation. The British had already included these explanations in the comment PD 6705-2:2010 to BS EN 1090-2 [22]. We should also include two similar British tables, tables IV and V in the NA national annex to PN-EN 1090-2 or PN-EN 1993-2.

Table IV. Service categories for steel bridges

\begin{tabular}{|c|c|c|c|c|c|}
\hline \multicolumn{2}{|c|}{ Level of service stresses } & \multirow{2}{*}{$\begin{array}{l}\text { Quantified } \\
\text { service } \\
\text { category }\end{array}$} & \multicolumn{2}{|c|}{ Static utilization factor $\mathrm{k}$} & \multirow{2}{*}{$\begin{array}{l}\text { Minimum required value } \\
\text { of reference fatigue } \\
\text { strength } \Delta \sigma_{\mathrm{C}}\end{array}$} \\
\hline Static & Fatigue & & & & \\
\hline Reduced & Very low & $\begin{array}{l}\text { F36 } \\
\text { F36 } \\
\text { F36 }\end{array}$ & $\begin{array}{l}\text { Tension } \\
\text { Shear } \\
\text { Compression }\end{array}$ & $\begin{array}{l}\mathrm{k} \leq 0.6 \\
\mathrm{k} \leq 0.8 \\
\mathrm{k} \leq 0.8\end{array}$ & $\Delta \sigma_{\mathrm{C}} \leq 36 \mathrm{MPa}$ \\
\hline Full & Low & F56 & - & $\mathrm{k} \leq 1.0$ & $\Delta \sigma_{\mathrm{C}} \leq 56 \mathrm{MPa}$ \\
\hline Full & Significant & $\begin{array}{l}\text { F71 } \\
\text { F90 } \\
\text { F112 } \\
\text { F140 }\end{array}$ & $\begin{array}{l}- \\
- \\
-\end{array}$ & $\begin{array}{l}\mathrm{k} \leq 1.0 \\
\mathrm{k} \leq 1.0 \\
\mathrm{k} \leq 1.0 \\
\mathrm{k} \leq 1.0\end{array}$ & $\begin{array}{l}\left(56<\Delta \sigma_{\mathrm{C}} \leq 71\right) \mathrm{MPa} \\
\left(71<\Delta \sigma_{\mathrm{C}} \leq 90\right) \mathrm{MPa} \\
\left(90<\Delta \sigma_{\mathrm{C}} \leq 112\right) \mathrm{MPa} \\
\left(112<\Delta \sigma_{\mathrm{C}} \leq 140\right) \mathrm{MPa}\end{array}$ \\
\hline
\end{tabular}

Table V. Examples of service category in the function of element and bridge types

\begin{tabular}{llll}
\hline \begin{tabular}{l} 
Quantified $\begin{array}{l}\text { service } \\
\text { category }\end{array}$ \\
\cline { 2 - 4 } F56
\end{tabular} & Pedestrian & Highway & Railway \\
F71 & $\begin{array}{l}\text { Special cases where } \\
\text { very susceptible } \\
\text { to crowd or wind } \\
\text { induced oscillation }\end{array}$ & $\begin{array}{l}\text { Cross girders } \\
\text { Short span non-composite bridges } \\
\text { Cain girders on medium to long spans }\end{array}$ & $\begin{array}{l}\text { Main girders on medium to long } \\
\text { span bridges with heavy ballasted } \\
\text { or concrete decks } \\
\text { Main girders on short span heavy } \\
\text { ballasted deck bridges }\end{array}$ \\
F90 & Steel decks with thin road surfacing & $\begin{array}{l}\text { Main girders, cross girders and } \\
\text { steel decks on short light weight } \\
\text { steel bridges }\end{array}$ \\
\hline
\end{tabular}

To sum up, the statement of prof. Henryk Zobel, chairman of the Construction and Building Structures Sector Council in the Polish Committee for Standardization, that with the current standardization policy: "Poland will only be a consumer of innovation created in other European countries, that is, not a creator, but a reproducer".

Author Contributions: Conceptualization B.W. and K.K.; methodology B.W. and K.K.; software K.K; validation K.K. and B.W.; formal analysis K.K.; investigation B.W. and K.K.; resources B.W.; data curation B.W. and K.K.; writing - original draft preparation B.W.; writing - review and editing K.K.; visualization K.K and B.W.; supervision B.W.

Funding: This research received no external funding

Conflicts of Interest: The authors declare no conflict of interest.

\section{References}

[1] Wichtowski B., Fatigue strength of welded butt joints in steel railway bridges. Scientific Works of the Szczecin University of Technology No 572. Publishing house of the Szczecin University of Technology, Szczecin, Polnad 2002 (in polish).

[2] Wiśniewski D.F., Casas J.R., Ghosn M., Codes for Safety Assessment of Existing Bridges - Current State and Further Development. Structural Engineering International, 2012, Vol. 22(4).

[3] Siwowski T., Fatigue life of road truss bridges with a riveted structure. Inżynieria i Budownictwo, 2014, Vol 8 (in polish).

[4] Wysokowski A., Durability of steel bridges as a function of fatigue and corrosion phenomena. IBDiM, Series: Study and Materials No. 53, Warsaw, Poland 2001 (in polish).

[5] Pipinato A. (editor), Innovative Bridge Design Handbook. Construction, Rehabilitation and Maintenance. Elsevier Inc., Amsterdam-Tokyo 2016.

[6] Klimpel A., Quality control and assurance in welding, Vol. 1. Publishing house of the Silesian University of Technology, Gliwice, Poland 1998 (in polish). 
[7] Rykaluk K., Cracks in steel structures. DWE, Wrocław, Poland, 1999 (in polish).

[8] Wiśniewski D., Majka M., Bień J., Assessment of the load capacity of bridges during their operation - domestic and foreign experience. Inżynieria i Budownictwo, 2013, No 7-8.

[9] Al-Emrani M., Aygül, Fatigue Design of Steel and Composite Bridges. Department of Structural Engineering, Chalmers University of Technology, Report 2014, Göteborg, Sweden 2014.

[10] Kühn B. et al, Assessment of existing steel structures: recommendations for estimation of remaining fatigue life. JRC Scientific and Technical Report No. 43401. European Commission, Joint Research Centre, Luxemburg 2008.

[11] Hobbacher A., Kassner M., On Relation between Fatigue Properties of Welded Joints, Quality Criteria and Groups in ISO 5817. IIW - document XIII-2323-10.

[12] Wichtowski B., Wichtowski M., Analysis of fatigue tests results of steel elements in the light of the requirements of European standards. Welding Technology Review, 2018, Vol. 90(5), 90-94. https://doi.org/10.26628/ps.v90i5.905

[13] Wichtowski B., Konecki K., Stress distribution in a steel butt joint with double-sided diamond caps determined by the finite element method. Inżynieria i Budownictwo, 2020, No 12 (in polish).

[14] Wichtowski B., Konecki K., Analiza obliczeniowa metodą elementów skończonych pęknięć zmęczeniowych w złączu stalowym doczołowym z jednostronnymi nakładkami rombowymi. Inżynieria i Budownictwo, 2021, No 3 (in polish).

[15] Wichtowski B., Konecki K., Summary of the computational analysis of a steel butt joint with diamond plates using the finite element method. Inżynieria i Budownictwo, 2021 (in polish, in press).

[16] Inglis C.E., Stresses in a plate due to the presence of cracks and sharp corners. Transactions of the Institute of Naval Architects. 1913, Vol. 55.

[17] Neuber H., Theory of notch stresses principles for exact stress calculation. J.W. Edwards, Ann Arbor, Michigan 1946.

[18] Sachs N.W., Understanding the Surface Features of Fatigue Fractures: How They Describe the Failure Cause and the Failure History. Journal of Failure Analysis and Prevention, 2005, Vol.5(2).

[19] Kocańda S., Fatigue cracking of metals, WNT, Warsaw, Poland, 1985 (in polish).

[20] Wyrzykowski J.W., Pleszakow E., Sieniawski J., Metal deformation and fracture, WNT, Warsaw, Poland, 1999 (in polish).

[21] Neimitz A., Fracture mechanics. WN PWN, Warsaw, Poland 1998 (in polish).

[22] Published document PD 6705-2:2010 Structural use of steel and aluminum. Part 2: Recommendations for the execution of steel bridges to BS EN 1090-2.

(C) 2021 by the authors. Submitted for possible open access publication under the terms and conditions of the Creative Commons Attribution (CC BY) license (http://creativecommons.org/licenses/by/4.0/). 